\title{
Evaluation of the Policy of Quality Assurance in Public and Private Sector Universities in Pakistan
}

Mujtaba Ahmad*

Dr. Muhammad Munir Kayani*

Dr. Azhar Mahmood ${ }^{* * *}$

\begin{abstract}
Quality assurance is increasingly becoming an important aspect of universities in developing countries. Development and implementation of quality assurance in universities is a challenge. The objectives of the study were to evaluate policy of quality assurance in public and private sector universities in Pakistan, to assess the practices of quality assurance in public and private sector universities in Pakistan, to find out the gap in policy and practices of quality assurance in public and private sector universities in Pakistan. Research design of the study was descriptive. The population of the study was 22 directors of quality enhancement cells, 3265 Ph.D. teachers and 288 heads of the department in sixteen public and six private sector universities in Islamabad. Through stratified random sampling technique, the sample of the study included 515 teachers, 215 HODs and 20 directors of QECs from the sixteen public and six private sector universities in Islamabad. Policy and practices of quality assurance in public and private sector universities was evaluated through questionnaire and interviews. Quantitative data were analyzed with the help of SPSS, Mean score, t-test and percentage. Public sector universities' staff was more skilled and performing their duties according to required standard. Public sector universities promote research culture among faculty and students. It was recommended by the researcher that local and international training on policy and practices of quality assurance should be given to QECs staff, HODs and faculty members.
\end{abstract}

Keywords: Quality Assurance, Higher Education, Policy, practice

\section{Introduction}

Higher education is most important for dynamic, forceful contribution in the knowledge societies. Higher education increases, race up social and economic development and progress. Quality education is a pre-requisite to obtain access to new knowledge and research that ensures social and economic improvement and development. Quality education in university education is a very serious challenge these days in Pakistan. Quality of higher education in Pakistan is not up to the mark. Identifying this issue of quality education, Higher education commission of Pakistan is determined to quality assurance and upgrade present situation of bad quality of education in universities of Pakistan. Higher Education commission of Pakistan is resolute and stable to enhance, to improve higher education institutions in the country. For obtaining international standards quality, quality assurance and constant improvement are vital elements and essentials (HEC, 2018).

Criterions of quality and quality assurance universities and higher education institutions require to be developed largely to gain the aims of competition in global standards. There is need to produce the roots of a knowledge economy. There is race for quality and quality assurance in the world to compete in international in production and service. Knowledge

${ }^{*}$ PhD Scholar, International Islamic University Islamabad.

${ }^{* *}$ Associate Professor, International Islamic University Islamabad.

${ }^{* * *}$ Associate Professor, International Islamic University Islamabad.

$=$ International Research Journal of Education and Innovation 
based and economy based societies are trying best to win this race. Developing countries are also in this race with little resources and unskilled human capital. All policies, measures, planned processes, action procedures, and activities used to maintain, improve, and develop the quality of higher education are included in quality assurance in higher education. The degree to which higher education satisfies the client's needs, expectations, and requests can be defined as its quality. In this regard higher education has two different customers: that are known as students and society. Both have equal importance in their place. Both have their own demands, requirements and needs (Harvey \& Williams, 2020).

University education in developing countries is changing due to recent development in the world. Majority of the developing countries in the world have started working on ongoing reforms due to quick expansion and development in the higher education area as well as hence provoke numerous matters and tasks. The problem at the system level is to strike a balance between the needs of increasing universities and the provision of high-quality education. The problem at the institutional level is to discover or develop new precise and scientific methods for assessing, quantifying, and insuring the quality of outputs. Due to a lack of financial resources and technically skilled personnel, developing countries face substantial obstacles in creating effective QA systems (San \& Kong, 2012).

During the last few years quality assurance has emerged as world problem related to criteria, values, principals of quality and standards. There is hunger and craving for quality, quality assurance in the whole world. There is quality war among different countries of the world. Many new models and frameworks have been proposed for the development of educational quality and quality assurance in universities around the world. National, provincial, and local quality assurance agencies have been established; efforts have been devoted to making more organised, widespread, and extensive quality assurance approaches; and many new models and frameworks have been suggested for the development of educational quality and quality assurance in universities around the world. Different countries of world have established quality assurance systems for developing and refining the quality and quality assurance in their universities and higher education institutions to compete in higher education arena. Universities are attracting student and due to world competion and rankings. Universities are accountable for their services, Outputs, results, consequences and financial sources utilized. Universities in different count rises of world and regions have been insisted and advised to assure and establish value, worth for their outputs and products (IIEP-UNESCO, 2011).

The educational profession has realised and observed an amazing competition for the development and implementation of quality assurance (QA) methods and procedures into higher education at the international, regional, and local levels (HE). Many global QA initiatives, as well as national collaborations, have been formed to support the successful and productive deployment and operation of QA. Although the procedures and ideas are not new, there is a rising recognition of the need of raising the quality of academic processes and university outcomes. In both public and private colleges, quality assurance is now seen as a vital phenomenon. In universities, quality assurance is a driving force in educational administration policies and accountability procedures (Martin \& Stella, 2007).

The quality of teaching and learning is currently the most serious issue in higher education institutions around the world. The Bologna Process has accelerated the implementation and development of quality assurance in European countries, as well as other parallel 
advancements. Most notably, a higher level of university independence and accountability, as well as a comparison of educational goods rankings, have become an essential component of university administrators' everyday work under the new public management concept. The Bologna process attempts to make degrees and learning outcomes more comparable across European university systems in order to improve student and labour mobility among European higher education institutions (Vught \& Boer 2015).

Contact between teachers, students, and the institutional learning environment has a big impact on quality. Quality assurance should ensure that the content of programmes, learning opportunities, and services is appropriate for the intended audience. All of this should be done with a specific goal in mind. Quality is a dynamic, ever-changing pursuit of perfection that must be viewed in the context of wider educational, economic, political, and social circumstances. Globalization in the higher education has affected in greater claim for quality assurance, responsibility and transparency. Universities and colleges are advised to apply quality assurance of their programs. Defining quality is significant requirement for defining quality assurance. Quality assurance is a resource that allows an organisation to guarantee, with trust and faith, that the principles of its educational provisions are being upheld and systems are being improved (Smidt, 2015).

The study was important due to its practical contributions. This provides vital knowledge about current policy and practices of quality assurance to universities to other higher education organizations and governmental establishments. The study also helps to increase the perception of participants about issues in developing and implementation of quality assurance. The research provides knowledge to policy makers and stakeholders in higher education. The quality assurance of universities was matter of top priority on the political and educational programs of government and higher education organizations.

\section{Objective of the Study}

The aim of this study was to evaluate the policy of quality assurance in public and private sector universities in Pakistan.

\section{Research Methodology}

Research design of the study was descriptive. The population of the study was 22 directors of quality enhancement cells, 3265 Ph.D. teachers and 288 heads of the department in sixteen public and six private sector universities in Islamabad. Through stratified random sampling technique, the sample of the study included 515 teachers, 215 HODs and 20 directors of QECs from the sixteen public and six private sector universities in Islamabad. Policy and practices of quality assurance in public and private sector universities was evaluated through questionnaire and interviews. Quantitative data was analyzed with the help of SPSS, Mean score, t-test and percentage. Public sector universities' staff was more skilled and performing their duties according to required standard. Public sector universities promote research culture among faculty and students. It was recommended by the researcher that local and international training on policy and practices of quality assurance should be given to QECs staff, HODs and faculty members.

\section{Results}

Table 1 Inclusion of Intended Learning Outcomes in the programs /courses 


\begin{tabular}{llllllll}
\hline \hline Responses & Public & $\%$ & Mean & Private & $\%$ & Mean & t-test \\
\hline SA & 133 & 39 & 3.23 & 90 & 53 & 3.02 & 2.35 \\
A & 100 & 29 & & 10 & 6 & & \\
U & 08 & 2 & & 05 & 3 & & \\
DA & 66 & 19 & & 43 & 26 & & \\
SDA & 39 & 11 & & 21 & 12 & & \\
Total & 346 & 100 & & 169 & 100 & & \\
\hline
\end{tabular}

*significant $\mathrm{df}=4 \quad$ Value of t-test at $0.05=2.132$

Table 1 shows that $39 \%$ of public sector respondents were strongly agreed with inclusion of intended learning outcomes in the programs /courses of the university whereas 53\% respondents of private sector universities were strongly agreed. Mean score of public sector is 3.23 however the mean score of private sector3.02 universities is 3.02. It shows that public sector universities are better than private sector in the inclusion of intended learning outcomes in the programs / courses of the university. The result of calculated t-test 2.35 also shows that public sector universities are better performing in inclusion of intended learning outcomes in the programs /courses of the university. Calculated value of t-test (2.35) is greater than table value 2.13 at 0.05 level. Mean score of public sector is bigger than private sector.This verifies that public sector is more practicing the policy of quality assurance than private sector.

Table 2 Integration of Intended Learning Outcomes into mission statement

\begin{tabular}{llllllll}
\hline Responses & Public & $\%$ & Mean & Private & $\%$ & Mean & t-test \\
\hline SA & 103 & 29 & 2.57 & 46 & 28 & 2.30 & 3.18 \\
A & 23 & 7 & & 14 & 8 & & \\
U & 07 & 2 & & 04 & 02 & & \\
DA & 49 & 14 & & 36 & 21 & & \\
SDA & 164 & 48 & & 69 & 41 & & \\
Total & 346 & 100 & & 169 & 100 & & \\
\hline
\end{tabular}

*significant $\mathrm{df}=4 \quad$ Value of t-test at $0.05=2.13$

Table 2 illustrates that only $29 \%$ of public sector respondents were strongly agreed and $48 \%$ strongly disagree with intended learning outcomes are integrated into mission statement_of the university whereas $28 \%$ respondents of private sector universities were strongly agreed. $41 \%$ of private sector universities were strongly disagreed. Mean score of public sector is 2.57 whereas the mean score of private sector universities is 2.30. It shows that public sector universities are better than private sector that intended learning outcomes are integrated into mission statement of the university. The result of calculated t-test is 3.18 also shows that public sector universities are better practicing the policy of quality assurance regarding the Integration of Intended Learning Outcomes into mission statement. The value of calculated ttest (2.57) is greater than the table value (2.13) at 0.05leval. It can be concluded that public sector universities more integrate Intended Learning Outcomes into mission statement. Table 3 Reflection of Intended Learning Outcomes for the use of external reference standards at appropriate level

\begin{tabular}{llllllll} 
Responses & Public & $\%$ & Mean & Private & $\%$ & Mean & t-test \\
\hline SA & 103 & 30 & 3.08 & 34 & 20 & 2.47 & 3.57 \\
A & 65 & 19 & & 25 & 15 & &
\end{tabular}




\begin{tabular}{lllll}
\hline \hline $\mathrm{U}$ & 36 & 10 & 02 & 01 \\
$\mathrm{DA}$ & 42 & 12 & 33 & 20 \\
$\mathrm{SDA}$ & 100 & 29 & 75 & 44 \\
Total & 346 & 100 & 169 & 100 \\
\hline *significant & $\mathrm{df}=4$ & & Value of t-test at $0.05=2.13$
\end{tabular}

Table 3 tells that $30 \%$ of public sector respondents were strongly agreed intended learning outcomes reveal the use of outside standards at suitable stage of the university however $20 \%$ respondents of private sector universities were strongly agreed. Mean score of public sector is 3.08 however the mean score of private sector_universities is 2.47 . It shows that public sector universities are better than private sector in intended learning outcomes reveal the use of outside standards at suitable stage in the universities. The result of calculated t-test 3.57 also shows that public sector universities are better performing. Intended learning outcomes better reveal the use of outside standards at suitable stage in the public sector universities. The value of calculated t-test (2.57) is greater than the table value (2.13) at 0.05 leval. This verifies the above description and statement also.

Table 4 Satisfaction of Intended Learning Outcomes however writing through self-assessment for external assessment of $Q A$

\begin{tabular}{llllllll}
\hline Responses & Public & $\%$ & Mean & Private & $\%$ & Mean & t-test \\
\hline SA & 135 & 39 & 3.28 & 36 & 21 & 2.53 & 2.84 \\
A & 69 & 20 & & 34 & 20 & & \\
U & 10 & 03 & & 01 & 01 & & \\
DA & 23 & 07 & & 11 & 07 & & \\
SDA & 109 & 31 & & 87 & 51 & & \\
$\quad$ Total & 346 & 100 & & 169 & 100 & & \\
* significant & $\mathrm{df}=4$ & & & Value of t-test at $0.05=2.13$
\end{tabular}

Table 4 tells that $39 \%$ of public sector universities respondents were strongly agreed that intended learning outcomes satisfy but reporting through self-assessment for external assessment of quality assurance however 21\% respondents of private sector universities were strongly agreed. Mean score of public sector is 3.28 though the mean score of private sector_universities is 2.53. It shows that public sector universities are better than private sector in intended learning outcomes satisfy whereas reporting through self-assessment for external assessment of quality assurance in the universities. The result of calculated t-test 2.84 also shows that public sector universities are better performing. Intended learning outcomes better reveal the use of outside standards at suitable stage in the public sector universities.

\section{Conclusion}

Intended learning outcomes (ILO) are given more importance and included in the programs/ courses of public sector universities. In private sector universities Intended learning outcomes (ILO) are ignored to some extent. The curricula for the programs facilitate realization of intended learning outcomes and quality of curricula plays important role in defining the quality of teaching and learning outcomes in public sector universities more than private sector universities. Private sector universities are not paying attention to the improvement and implementation of curricula. Public sector universities reveal the use of 
Intended Learning Outcomes (ILO) but the condition in private sector universities is worse. Curricula is more better practiced in public sector universities.

\section{Recommendations}

1. Local and international training on policy and practices of quality assurance should be given to QECs Staff, heads of department and faculty members.

2. Policy of quality assurance be updated.

3. 3. Quality assurance awareness campaign be started in public and private Sector universities in Pakistan

4. Co-ordination be increased among administration, teaching staff, students and QECs staff.

\section{References}

1. Airasian, P \&L.R. Gay (.2000.) Educational Research: Competencies for Analysis and Application sixth Edition. New Jersey: Prentice Hall Inc.

a. Banta, T.W. \&Palombi, C.A. (2015), Assessment Essentials: Planning, Implementing, and Improving Assessment in Higher Education, Jossey-Bass, San Francisco, CA.

2. Bowen, W.H., (2015). The History of Saudi Arabia, 2nd edn. Santa Barbara: ABC Clio.

3. Creswell, J.W. (2009). Mapping the Field of Mixed Methods Research, Journal of Mixed Methods Research, 3 (2), pp. 95-108.

4. Harvey, L., \& Williams, J. (2020). Fifteen years of Quality in Higher Education. Quality in Higher Education, 16(1), 3-36.

5. Higher Education Commission. (2018). Developing the Performance Evaluation Standards for the HEIs.

6. IIEP-UNESCO. (2011). External quality assurance: options for higher education managers: Training modules. IIEP- UNESCO.

7. Kezar, A., et al. (2008). Examining Organizational Contextual Features that Affect Implementation of Equity Initiatives. The Journal of Higher Education, 79(2):125-159

8. Martin, A. and Stella, P. (2007). Meeting today's governance challenges: A synthesis of the Literature and examination of a future agenda for scholarship. The Journal of Higher Education, 75(4):371-399.

9. San, J., \& Kong, F. (2012). The University of learning: beyond quality and competence. New York: Routledge.

10. Srikanthan, G., \& Dalrymple, J. (2004). A synthesis of a quality management model for education in universities. International Journal of Educational Management, 18(4), 266- 279.

11. UNESCO (2006). Global Education Digest 2006. Montreal: UNESCO Publishing.

12. UNESCO. (2007). Global Education Digest 2007: Comparing education statistics across the world. Montreal, Canada: UNESCO Institute of Statistics. 